\title{
Study of the snail intermediate hosts for Schistosoma mansoni on Itamaracá Island in northeast Brazil: spatial displacement of Biomphalaria glabrata by Biomphalaria straminea
}

\author{
Constança S. Barbosa ${ }^{1}$, Verônica S. Barbosa ${ }^{1}$, Wheverton C. Nascimento ${ }^{1}$, Otavio S. Pieri ${ }^{2}$, \\ Karina C. G. M. Araújo ${ }^{3}$ \\ ${ }^{1}$ Laboratório e Serviço de Referência em Esquistossomose, Centro de Pesquisas Aggeu Magalhães, FIOCRUZ, \\ Recife, Brazil; ${ }^{2}$ Laboratório de Ecoepidemiologia e Controle da Esquistossomose e Geohelmintoses, Instituto \\ Oswaldo Cruz, FIOCRUZ, Rio de Janeiro, Brazil; ${ }^{3}$ Programa de Pós-Graduação em Biologia Parasitária e \\ Núcleo de Pós-Graduação em Medicina, Universidade Federal de Sergipe, Aracaju, Brazil
}

\begin{abstract}
In 2012 a malacological survey of the breeding sites of Biomphalaria glabrata and B. straminea, the two intermediate host snails of Schistosoma mansoni, was carried out on Itamaraca Island in Pernambuco, Brazil. This study has now been extended by studying the competition between the two species. Snails were collected and dissected to identify the species and tests were performed to verify $S$. mansoni infection. Student's $t$ test was used to compare the proportion between the two species and their breeding sites and a parasitological survey was conducted among local residents, using the Kato-Katz method. The spatial distribution of the two snail species was determined using TerraView, while a snail density map was constructed by Kernel estimate. The survey identified two breeding sites for B. glabrata with 17 specimens and 19 breeding sites for $B$. straminea with 459 snails, all of them negative for $S$. mansoni infection. The statistical analysis revealed that the proportion of the numbers of specimens and breeding sites of $B$. straminea $(37.84 \pm 9.01)$ were significantly greater than those of B. glabrata $(8.50 \pm 6.50)$. Parasitological examinations from 41 residents diagnosed two cases of schistosomiasis with parasite loads of 60 and 84 eggs per $1 \mathrm{~g}$ of stool, respectively. This indiction of a competitive process between the two snail species requires monitoring of schistosomiasis in the resident and travelling human populations occupying this environment, which could potentially result in social and economic changes on the island risking its attraction as a centre for eco-tourism.
\end{abstract}

Keywords: urban schistosomiasis, Biomphalaria, competitive displacement, spatial analysis, geographical information system, Brazil.

\section{Introduction}

Schistosomiasis mansoni is a highly prevalent, poverty-related disease caused by infection with a trematode worm of the species Schistosoma mansoni. From 2008 to 2012, a survey based on 7.1 million stool examinations was carried out by the Schistosomiasis Control Program (SCP) in 1,060 endemic municipalities throughout Brazil. Out of the people tested, $5.4 \%$ was found to be positive for S. mansoni, allowing an estimate of 2.1 million infected and 38.3 million at risk in the country. In the rural endemic areas of Pernambuco State, the SCP

\footnotetext{
Corresponding author: Constança S. Barbosa

Laboratório e Serviço de Referência em Esquistossomose

Av. Prof. Moraes Rego, S/n. Cidade Universitária, CEP: 50.670-420

Centro de Pesquisas Aggeu Magalhães

Fundação Oswaldo Cruz (FIOCRUZ)

Recife, Pernambuco, Brazil

Tel. + 5581 2101-2572

E-mail: cbarbosa@cpqam.fiocruz.br
}

recorded significantly less egg-positivity in the 20082012 period $(49,062 / 826,269=5.9 \%)$ than in the previous 5-year period between 2003 and 2007 $(149,079 / 1,063,282=14.0 \%)$ (Ministério da Saúde, 2013). The part of the 2008-2012 survey, carried out on the island of Itamaracá near the city of Recife on the northern coast of Pernambuco, included 4,256 stool examinations. People in rural communities with the exception of coastal villages were surveyed and 105 cases $(2.5 \%)$ of $S$. mansoni infection were found (Ministério da Saúde, 2013).

The two intermediate hosts of S. mansoni in Brazil are the planorbid snails Biomphalaria glabrata and B. straminea. The first occurrence of B. straminea, at different locations on Itamaracá Island, dates from 1977 and was found through a survey conducted by the National Health Foundation (FUNASA). Subsequent investigations detected the presence of two species of Biomphalaria on the island, but always at equidistant locations and with different ecological characteristics (Barbosa et al., 2000, 2004). The first records of autochthonous human schistosomiasis 
cases and infected intermediate host snails emanate from Fort Orange beach in 1991, when four medical students became infected through accidental exposure in streets that were full of B. glabrata snails after being flooded due to heavy rains. On that occasion, $19.7 \%$ of 7,217 snails collected were releasing S. mansoni cercariae and 12 streets were identified as snail breeding (Gonçalves et al., 1991). The first epidemiological plan of the locality was produced in 1997 showing two remnant lagoons from the original ecosystem and a parasitological survey diagnosed 10 autochthonous human cases among the 349 vacationers sampled (Barbosa et al., 1998). Among the 91 local residents sampled (fishermen, home caretakers and civil construction workers), the prevalence of schistosomiasis was $41.8 \%$, thus showing the strong local expression of the disease at that time (Barbosa et al., 1998).

Between 1997 and 2002, six malacological surveys were conducted at Fort Orange beach by the Schistosomiasis Laboratory of the Aggeu Magalhães Research Center (CPqAM), Oswaldo Cruz Foundation (FIOCRUZ), comprising active searches of 27 peridomestic foci, identified and georeferenced in the streets. Over this period, a total of 5,009 B. glabrata snails were collected, with natural infection rates varying monthly from $3.3 \%$ to $28.8 \%$. In 2003, georeferenced maps showing the potential environmental risk of human contamination represented by $B$. glabrata foci were drawn up and handed over to the local health department. The episodic nature of schistosomiasis at Fort Orange beach, highlighting the ecological, environmental and sanitary characteristics supporting local schistosomiasis transmission has been discussed by Barbosa et al. (1998, 2000, 2004).

Between 2006 and 2008, the Schistosomiasis Laboratory organised two field expeditions with the aim of georeferencing snail breeding sites and foci present along the entire coastline of the state of Pernambuco (EpiSchisto Risk Modeling, 2008). The ecological valence of the two potential intermediate host snails differs. B. straminea has a high capacity to populate extensive and varied environments and has also a greater capacity to resist periods of drought, qualities that enable and regulate the expansion of this eurytopic species (Barbosa and Barbosa, 1994). B. glabrata, on the other hand, has a smaller geographical distribution in the state of Pernambuco where its occurrence is restricted to coastal localities. However, the epidemiological importance of this species stands out because of its high natural infection rate, which threatens exposed human populations. Barbosa et al. (2000) tested the potential for cercaria release by $B$. glabrata experimentally at Forte Orange beach and found an average of 394.6 cercariae per snail, after 5 min of light exposure.

Paraense (1970) formulated the hypothesis that competitive exclusion between Biomphalaria species influences the distribution of its populations. Authors like Hubendick (1958) and Michelson and Dubois (1979) have reported on the capacity of B. straminea to replace $B$. glabrata under laboratory and field conditions. Over a 3-year period, Barbosa (1973) observed that autochthonous B. glabrata snails being displaced by invasive $B$. straminea ones in a locality in the metropolitan region of Recife, Pernambuco, suggesting the possibility that competitive displacement was taking place. In 1992, the same author followed up this phenomenon between the two species by means of laboratory experiments (Barbosa et al., 1992) and in 1993, the competitive capacity of B. straminea to replace B. glabrata was induced and confirmed under experimental field conditions (Barbosa et al., 1993). This observation confirmed what was stated by Michelson and Dubois (1979) that the competitive capacity of $B$. straminea, in comparison with $B$. glabrata, highlighting its higher reproductive rate and capacity to invade territories.

The objective of the present study was to conduct a new malacological survey at Fort Orange beach, to update available information on the distribution of the two snail species in this locality. The findings would be compared with previous records with the aim of unravelling a possible process of competitive displacement between these species.

\section{Material and methods}

\section{Study area}

The locality selected for this study was Fort Orange beach, coastal village located in the southern part of Itamaracá on the northern coast of Pernambuco State, Brazil. Itamaracá is an island municipality forming part of the metropolitan region of Recife, the state capital. The sampling space was in the south-western part of the island of Itamaracá and comprised $1 \mathrm{~km}$ of coastline delimited to the East by the sea and to the West by a highway (PE 001). The width between the highway and the sea is $300 \mathrm{~m}$ (Fig. 1). The geoecological limits defining the sampling space were a mangrove swamp contiguous with the Forte das Cinco Pontas to the South and to the North the Caboclo lagoon and creek covering the area between the streets Araras and Lavras. 


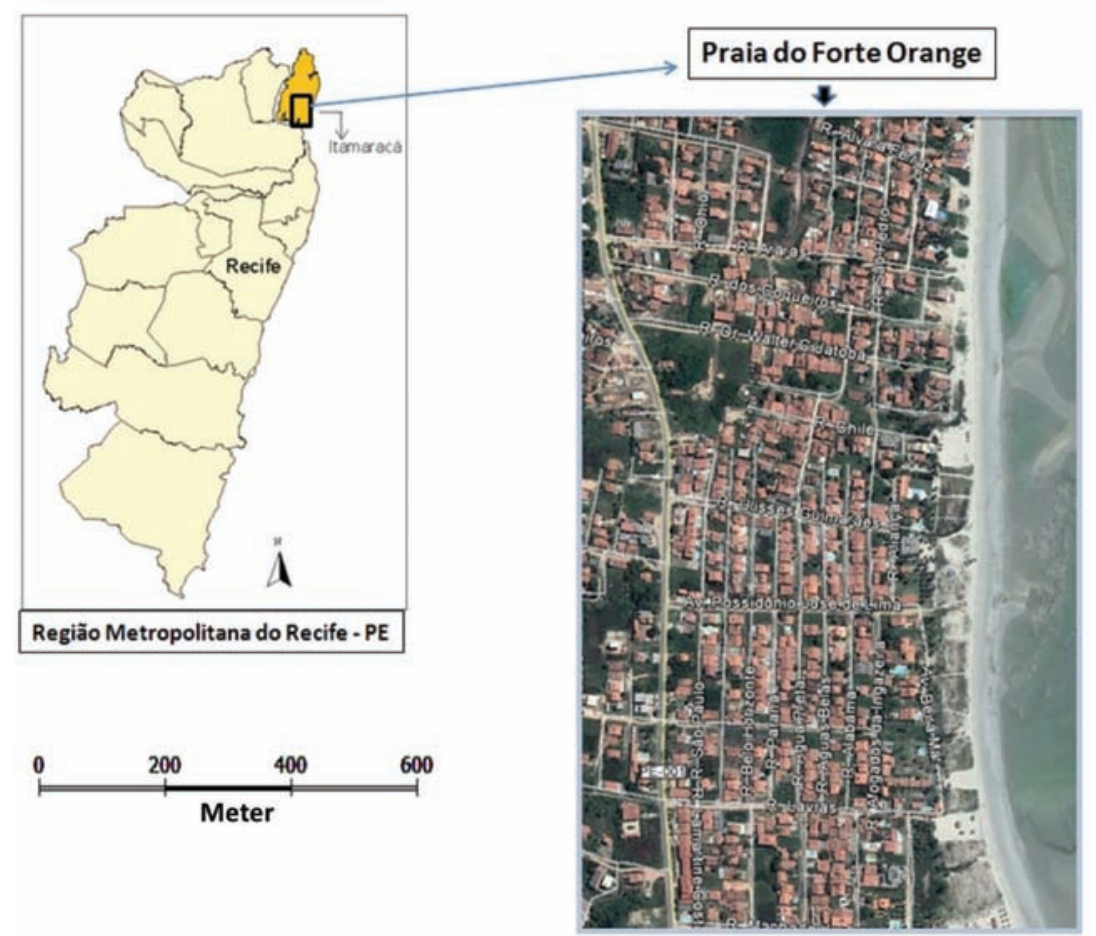

Fig. 1. Metropolitan area of Recife and satellite image showing the study area in Fort Orange beach village, Itamaracá in 2010. The mangrove forest in the South, the creek and lagoon to the North are outside the bounds of the satellite image.

Fort Orange beach is located $48 \mathrm{~km}$ from Recife. It receives large numbers of visitors from this city and the interior of the state of Pernambuco. The area delimited by our investigation includes vacation homes interspersed with small agglomerations of workers' homes occupied by local people, who are traders or service providers to the vacationers. There are also some uninhabited plots of land without landfills that forms depressions covered with vegetation that retain rainwater, maintaining moisture levels favouring snail survival during the dry season. The Family Health Unit (USF) of the locality attends to 1,040 families consisting of around 3,200 permanent residents. On public holidays and during the summer, this population may triple through occupation of the vacation homes and with the arrival of tourists at guesthouses and hotels.

\section{Malacological survey}

The malacological survey for this study was conducted in August 2012 after the area had been mapped identifying and georeferencing the breeding sites. It consisted of a systematic sweep (Oliver and Schneiderman, 1956) collecting snails from all water accumulations in the study area. These comprised flooded plots of land, rainwater runoff ditches and puddles of rainwater in the streets. The snails thus col- lected were taken to the laboratory to identify the species by dissecting the genitalia (Deslandes, 1951). S. mansoni infection was investigated by means of exposure to light stimulating cercaria release (Souza and Lima, 1990). B. straminea snails remaining negative were subjected to molecular diagnostics using the nested polymerase chain reaction (PCR) (Melo et al., 2006). S. mansoni DNA was extracted from 459 B. straminea specimens, in batches of up to 50 specimens/breeding site using the modified phenol-chloroform technique (Sambrook et al., 1989). During the malacological survey, a few local residents asked for parasitological tests to be performed. All in all, faecal samples from 41 people were collected and sent to the Schistosomiasis Laboratory at CPqAM for testing using the Kato-Katz method (Katz et al., 1972).

\section{Statistical analysis}

Student's $t$ test with the Welch correction (Welch, 1947) was used to compare the proportions of B. straminea and B. glabrata at the breeding sites utilizing the GraphPad Prism 5.0 software (Graph-Pad Software, San Diego, USA). The results were presented in terms of the mean number of snails per breeding site \pm standard error (SE) and differences were considered to be statistically significant when $\mathrm{P}<0.05$. 


\section{Processing of spatial data}

To create the cartographic base for the study, graphical data in digital media were acquired from the Municipal Development Foundation (FIDEM) (http://www.condepefidem.pe.gov.br). The northern growth map of the metropolitan region of Recife (1997) was used at the scale $1: 20,000$ as well as the topographic registration plans of the "Unificação das Bases Cadastrais" (UNIBASE) project (http://www.condepefidem.pe.gov.br) at the scale 1:1,000. To spatially locate the foci, the absolute method (Hofmann-Wellenhof et al., 1997) was used, with instantaneous positioning of points collected by means of a Garmin global positioning system (GPS) navigation receiver. Geographical coordinates were captured in the UTM projection system with the reference ellipsoid SAD69. The spatial distribution of the snails found was determined using TerraView 4.1.0 (http://www.dpi.inpe.br) and the analysis units comprised the street and block system of the Fort Orange beach, which have well-defined limits. For the purposes of comparison with the spatial data obtained in 2012, graphical and descriptive data from 2002 relating to the distribution of B. glabrata foci of at the same locality (Barbosa et al., 2004) were used. To estimate the spatial population density of the snail species collected, the technique of exploratory interpolation with kernel estimates was used (Bailey and Gattrel, 1995). By means of statistical smoothing or rounding, a density surface for visual detection of hot spots was generated. These hotspots were taken to be concentrations of events that in some way indicated agglomeration of a spatial distribution. This procedure made it possible to

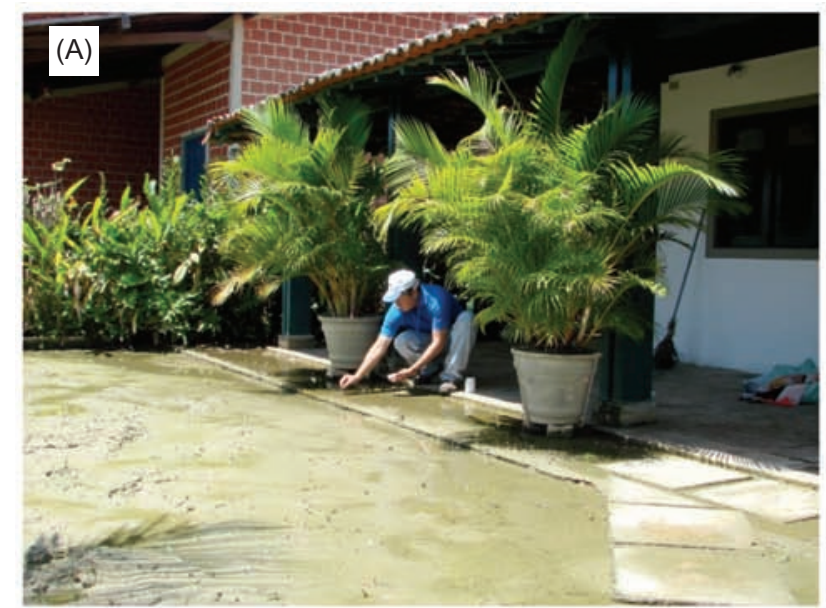

filter the variability of a dataset without altering the essential shape of its local characteristics (Bailey and Gatrell, 1995), thereby generating a continuous surface from the point data (Cromley and McLafferty, 2002).

\section{Results}

In the malacological survey conducted in 2002, 26 breeding sites/foci of B. glabrata, the only intermediate host for $S$. mansoni existing at Fort Orange beach at that time, were identified and mapped. In the current investigation (2012), it was noted that the study area remained unchanged with the same environmental and sanitary conditions observed in 1997: unpaved streets, drainage of wastewater and sewage directly into the streets and backyards full of snails (Fig. 2). This current survey detected only two breeding sites for B. glabrata and 19 new breeding sites for B. straminea, whose geographical coordinates can be seen within the street and block system of the locality (Fig. 3). From these sites, 17 B. glabrata snails and 459 B. straminea snails were collected. Fig. 3 shows the distribution of the population density of these two snail species.

All specimens of both snail species were found to be negative for cercariae of S. mansoni, in examinations using the technique of light exposure during a 15-day period and no vestiges of $S$. mansoni DNA were found in the B. straminea snails using nested PCR. B. glabrata was not investigated for DNA since landfills had drastically limited the natural environment of this species.

Considering the breeding sites together, the statistical analysis on the data revealed that the proportion of

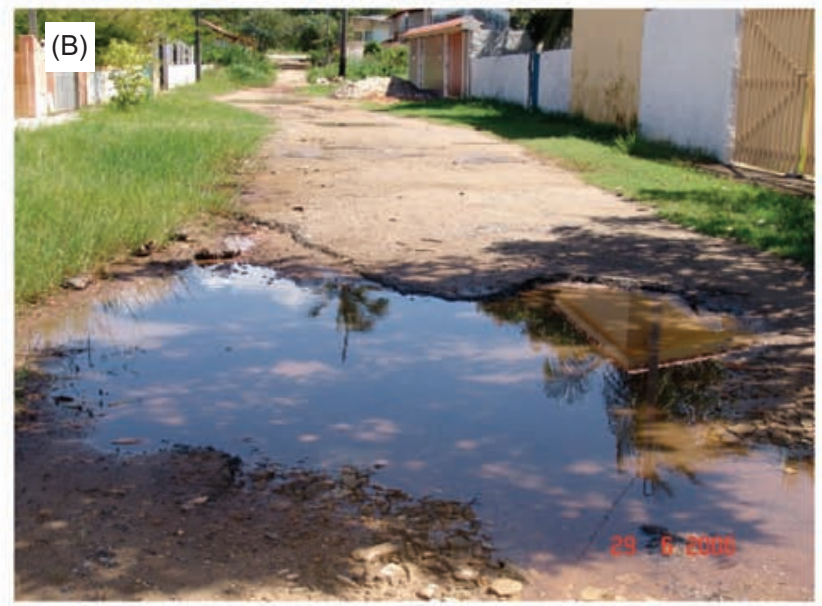

Fig. 2. Biomphalaria straminea snails in backyard of a residential building in Praia do Forte Orange, Itamaracá Island (A) and in a street in the same locality where the sewage is leaking (B). 


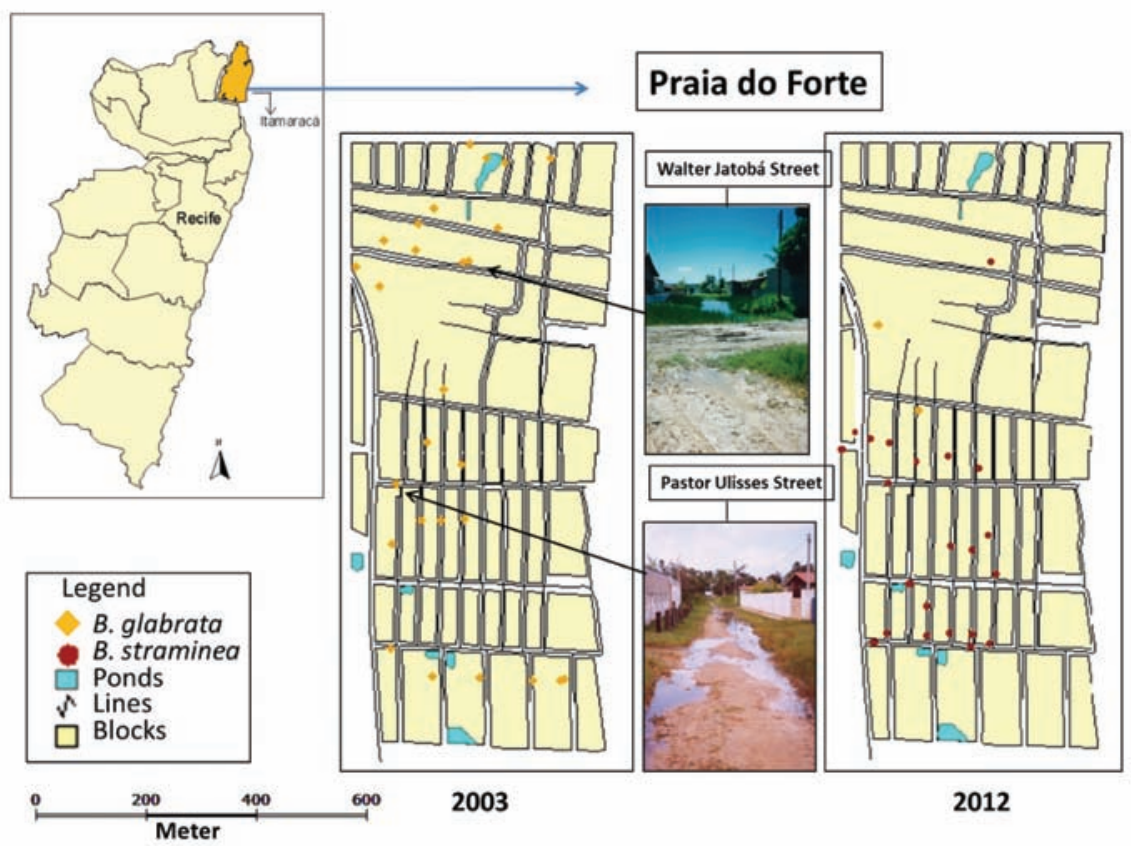

Fig. 3. Georeferenced map showing the spatial occupation by Biomphalaria glabrata and Biomphalaria straminea in Praia do Forte Orange, Itamaracá Island in 2003 and 2012.

the number of specimens and breeding sites accounted for by B. straminea $(37.84 \pm 9.01)$ was significantly greater than the proportion of B. glabrata $(8.50 \pm$ $6.50)$ with $P=0.033$. Fig. 4 shows the spatial concentration of the population densities of the snails of each species that were collected in the study area.

The stool examinations performed on the 41 resi- dents diagnosed two cases of schistosomiasis, with parasite loads of 60 and 84 eggs per $1 \mathrm{~g}$ of stool (EPG). The resident population within the sampling area of this study is around 450 people and, since there was no active search aimed towards conducting a coproscopic survey, no estimate of the real prevalence of schistosomiasis at this locality can be made.

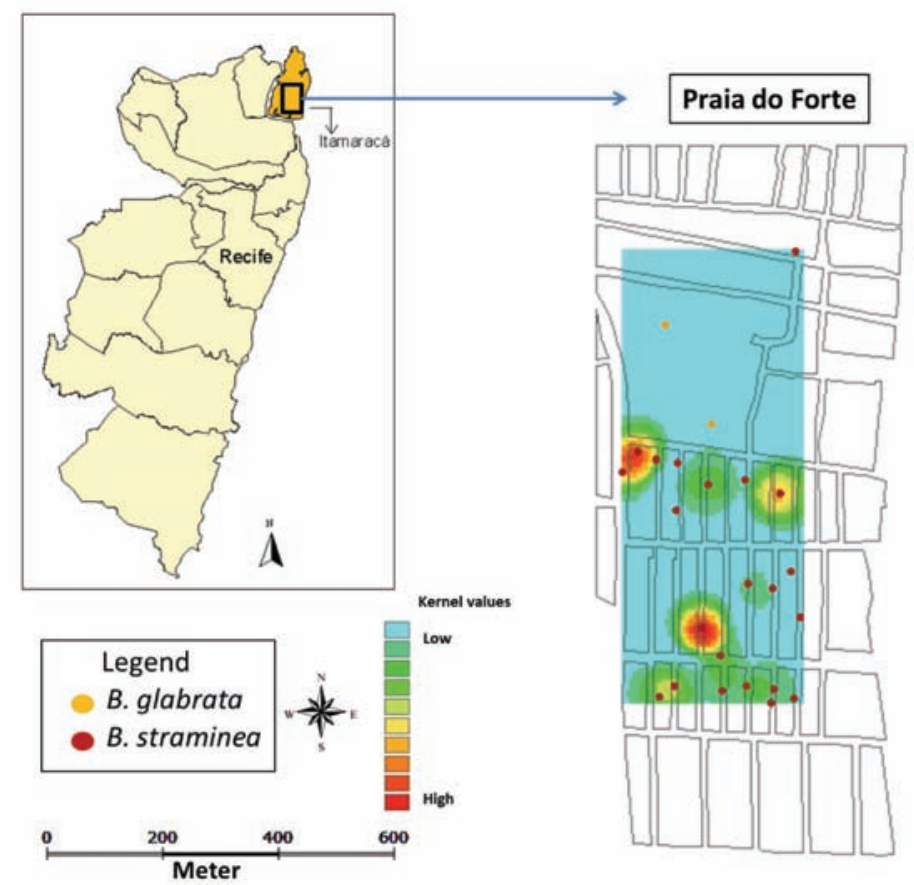

Fig. 4. Kernel map showing the current population density of Biomphalaria glabrata and Biomphalaria straminea in Praia do Forte Orange, Itamaracá Island in 2012. 


\section{Discussion}

Since the first records of schistosomiasis transmission in 1991, no environmental or sanitary improvements at Fort Orange breach have occurred. During the rainy season, the streets and backyards become flooded as the drainage ditches overflow, thus forming a water surface that is continuous with the snail breeding sites. The snails survive the dry season by sheltering in the damp conditions of freshwater marshes and flooded plots of land. From there, they are transported passively by the rainwater currents to the streets and to the backyards of people's homes, which become spaces presenting a risk of schistosomiasis transmission.

The seasonal condition described above promotes accidental confrontation between the two species of Biomphalaria at the same breeding sites, thus starting the phenomenon of competitive exclusion. These species present a tendency to occupy different habitats and, although they may occur in the same area, they are mutually exclusive and almost never found in the same water bodies due to their different ecological niches. The significant territorial occupation and population density of $B$. straminea after introduction into an area previously populated by B. glabrata for many years confirm the data in the literature attesting that B. straminea is not only an invasive and competitive species, but also a good coloniser of natural environments (Barbosa and Oliver, 1958; Michelson and Dubois, 1979).

Considering that B. straminea was found at this locality for the first time in September 2006, one must conclude that the replacement of B. glabrata by B. straminea has been occurring for at least 7 years. Modifications to the ecological niche of the latter species are likely to favour the exclusion of the former from this environment. Originally, B. glabrata survived throughout the year in the freshwater lagoon that existed there, but the surface area of this lagoon has been drastically reduced through landfills, thus limiting the natural environment of this species. On the other hand, B. straminea is not only more resistant to infection by S. mansoni, but tolerates also natural desiccation better. These factors modulate the selection pressure, thus favouring survival and colonization by this species in vacant land plots during the summer drought.

It is known that changes to the distribution of the intermediate host snail influences the morbidity caused by the disease in the human population (Kawazoe et al., 1980). Thus, it is possible that replacement of B. glabrata by B. straminea at the study locality may have had an impact in terms of reduction of the risk of disease transmission, considering that $B$. straminea is a relatively poor intermediate host for S. mansoni and that human exposure at that locality is accidental and seasonal. Replacement of the species may represent a protection factor for the population living in that environment, thus minimizing transmission and the risk related to exposure. However, it should be noted that relatively high rates of natural infection of $B$. straminea have been reported in the endemic areas of Pernambuco (Favre et al., 2002) due to systematic exposure of the rural populations to rivers, where they perform domestic or leisure activities.

In the light of this evidence, a new epidemiological scenario is formed. The observation that a competitive process exists between the snail species and the possibility that alternation in population density may exist between them require monitoring in order to prevent unforeseen consequences regarding the impact of schistosomiasis in the resident and mobile populations that occupy this environment. The discussion of these results remains limited at this point because the epidemiological investigation was merely observational, thus not allowing inferences regarding causality or any validation of correlations on the process. However, further research is called for, as postulated by Avila-Pires (2011): “... human ecology is essentially interdisciplinary, demanding a combination of theories and methods, both of exact sciences and of social sciences".

The municipality of Itamaracá is currently considered to be priority for the governmental sector that administrates the investment in eco-tourism in Pernambuco. The situation detected through this study may have social and economic repercussions for a state that intends to explore its potential for ecotourism and tropical resorts. The spatial properties of this coastal locality need to be reconfigured and lead to solutions improving sanitation and infrastructure actions in order to ensure that Itamaracá develops and continues as an important centre for ecological tourism.

\section{Acknowledgements}

We thank the research funding sources: SVS/MS (Ministry of Health - Brazil), CNPq, PROMOB and PROEF/CAPES/FAPITECSE.

\section{References}

Ávila-Pires FD, 2011. Human ecology, statistical analysis and the logic of valid correlations. Política e Sociedade 10, 57-69. 
Bailey T, Gatrell AC, 1995. Interactive spatial data analysis. New York: Longman Scientific \& Technical, 413 pp.

Barbosa CS, Araújo KC, Antunes L, Favre TC, Pieri OS, 2004. Spatial distribution of schistosomiasis foci on Itamaracá Island, Pernambuco, Brazil. Mem Inst Oswaldo Cruz 99, 7983.

Barbosa CS, Barbosa FS, Arruda F, 1993. Long-term controlled field experiment on the competition between two species of Biomphalaria (Mollusca, Basommatophora), the snail vectors of Schistosoma mansoni in Northeastern Brazil. Cad Saude Publica 9, 170-176.

Barbosa CS, Gonçalves JF, Barbosa FS, Albuquerque Y, 1998. Urban schistosomiasis in Itamaracá Island, Pernambuco, Brazil: epidemiological factors involved in the recent endemic process. Mem Inst Oswaldo Cruz 93, 265-266.

Barbosa CS, Pieri OS, Barbosa FS, 2000. Ecoepidemiologia da esquistossomose urbana na ilha de Itamaracá, Estado de Pernambuco. Rev Saude Publica 34, 337-341.

Barbosa FS, 1973. Possible competitive displacement and evidence of hybridization between two Brazilian species of planorbid snails. Malacologia 14, 401-408.

Barbosa FS, Barbosa CS, 1994. The bioecology of snail vectors for schistosomiasis in Brazil. Cad Saude Publica 10, 200-209.

Barbosa FS, Oliver L, 1958. Studies on the snail vectors of bilharziasis mansoni in north-eastern Brazil. Bull World Health Organ 18, 895-908.

Barbosa FS, Sanchez O, Barbosa CS, Arruda F, 1992. Dynamics of snail populations of Biomphalaria glabrata and B. straminea under semi-natural conditions. Cad Saude Publica 8, 157-167.

Cromley EK, McLafferty SL, 2002. GIS and public health. New York: Guilford Press, 340 pp.

Deslandes N, 1951. Técnicas de dissecção e exame de planorbídeos. Rev Serv Espec Saude Publica, 4, 371-382.

EpiSchisto Risk Modeling, 2008. Available at: http://200.17.137.109:8081/xiscanoe/projeto/cnpq-edital-universal-477703-2006-2 (accessed on June 2013).

Favre TC, Pieri OS, Zani LC, Beck, L, Barbosa CS, 2002. A longitudinal study on the natural infection of Biomphalaria straminea and B. glabrata by Schistosoma mansoni in an endemic area of schistosomiasis in Pernambuco, Brazil. Mem Inst Oswaldo Cruz 97, 465-475.
Gonçalves JF, Coutinho A, Santana W, Barbosa CS, 1991. Esquistossomose aguda de caráter episódico na Ilha de Itamaracá, PE. Cad Saude Publica 7, 424-425.

Hofmann-Wellenhof B, Lichtenegger H, Collins J, 1997. Global positioning system: theory and practice. New York: Springer, 386 pp.

Hubendick B, 1958. A possible method of schistosome-vector control by competition between resistant and susceptible strains. Bull World Health Organ 18, 1113-1116.

Katz N, Chaves A, Pellegrino J, 1972. A simple device for quantitative stool thick-smear technique in schistosomiasis mansoni. Rev Inst Med Trop São Paulo 14, 397-400.

Kawazoe U, Magalhães LA, Hotta LK, Takaku L, 1980. Biological competition between Biomphalaria glabrata (Say, 1818) and Biomphalaria tenagophila (d'Orbigny, 1835), observed in their natural breeding sites in Ourinhos, SP (Brazil). Rev Saude Publica 14, 65-87.

Melo FL, Gomes ALV, Barbosa CS, Werkaüser RP, Abath FGC, 2006. Development of molecular approaches for the identification of transmission sites of schistosomiasis. Trans $\mathrm{R}$ Soc Trop Med Hyg 100, 1049-1055.

Michelson EH, Dubois L, 1979. Competitive interactions between two snail hosts of Schistosoma mansoni: laboratory studies on Biomphalaria glabrata and B. straminea. Rev Inst Med Trop São Paulo 21, 246-253.

Ministério da Saúde. Datasus, 2013. Programa de Controle da Esquistossomose. Available at: http://tabnet.datasus.gov.br/cgi/ deftohtm.exe?sinan/pce/cnv/pce.def (accessed on June 2013).

Olivier L, Schneiderman M, 1956. A method for estimating the density of aquatic snail populations. Exp Parasitol 5, 109-117.

Paraense WL, 1970. Planorbideos hospedeiros intermediários do Schistosoma mansoni. USP, São Paulo, 13-30 pp.

Sambrook J, Fritch EF, Maniatis T, 1989. Molecular cloning: a laboratory manual. New York: Cold Spring Harbor Laboratory Press (second edition).

Souza CP, Lima LC, 1990. Moluscos de interesse parasitológico do Brasil, Série Esquistossomose. Fundação Oswaldo Cruz, Centro de Pesquisas René Rachou, Belo Horizonte, 79 pp. (second edition).

Welch BL, 1947. The generalization of “Student's" problem when several different population variances are involved. Biometrika 34, 28-35. 